\title{
PRAKTEK BAGI HASIL PETERNAKAN SAPI MASYARAKAT KECAMATAN BAREBBO KABUPATEN BONE SULAWESI SELATAN
}

\author{
Sitti Nikmah Marzuki \\ IAIN Bone, Sulawesi, Indonesia \\ Email: nikmah.marzuki@iain-bone.ac.id
}

\begin{abstract}
The Practice of Profit Sharing on Cattle Breeding in Improving Social Economy in Barebbo District, Bone Regency South Sulawesi, Indonesia. The practice of community livestock sharing is still a common problem that arises because the system of profit sharing is not clear, as well as if there is an event of force majeure at the time the agreement is divided. For example, there is a death of a calf from the results of a cattle farm or the parent of a cow that experiences death. This research reveals and analyzes the practice of profit sharing and income of cattle ranchers. This study uses data collection techniques through observation and interviews with qualitative descriptive analysis. The practice of cattle breeding in Barebbo Subdistrict The cattle farming system in Barebbo Subdistrict generally uses three systems, namely extensive maintenance techniques, intensive maintenance techniques and semi-intensive maintenance techniques with average farmer income of two million up to five million rupiahs per one cow depends on the condition of the cow and the agreed profit sharing technique. If the farmer cooperates with 2 cows, the farmer will have a greater advantage. The profit sharing system is based on what is done by the profit sharing system based on income, profit sharing based on gross profit and profit sharing based on net income. The most dominant revenue-sharing system used by cattle breeders in Barebbo Subdistrict is profit sharing based on gross profit. This system is seen as more just and provides benefits to both parties. This system can improve the economy of ranchers in Barebbo District, Bone Regency.
\end{abstract}

Keywords: Profit Sharing, Cattle Breeding, Social Economy, Rancher.

Abstrak. Praktek Bagi Hasil Peternakan Sapi Masyarakat Kecamatan Barebbo Kabupaten Bone Sulawesi Selatan, Indonesia. Praktik bagi hasil peternakan masyarakat masih sering terjadi permasalahan yang muncul karena sistem bagi hasil yang tidak jelas, seperti halnya jika terjadi peristiwa force majeur pada saat perjanjian bagi hasil. Misalnya terjadi kematian terhadap anak sapi dari hasil peternakan sapi atau induknya sapi yang mengalami kematian. Penelitian ini mengungkap dan menganalisis praktek bagi hasil dan pendapatan masyarakat peternak sapi. Penelitian ini menggunakan teknik pengumpulan data melalui observasi dan wawancara dengan analisis deskriptif kualitatif. Praktek bagi hasil peternakan sapi di Kecamatan barebbo Sistem peternakan sapi di Kecamatan Barebbo pada umumnya menggunakan tiga sistem yaitu teknik pemeliharaan ekstensif, teknik pemeliharaan intensif dan teknik pemeliharaan semi-intensif dengan pendapatan peternak rata dua juta sampai lima 
Islamiconomic: Jurnal Ekonomi Islam Vol.10 No.1 Januari - Juni 2019

$\overline{\text { juta rupiah setiap satu ekor sapi tergantung dari kondisi sapi dan teknik bagi hasil yang }}$ disepakati. Jika peternak melakukan kerjasama ternak sapi 2 sapi maka peternak akan memiliki keuntungan yang lebih besar. Sistem bagi hasil didasarkan pada yang dilakukan Sistem bagi hasil yang diterapkan berdasarkan pendapatan, bagi hasil berdasarkan laba kotor dan bagi hasil berdasarkan laba bersih. Sistem bagi hasil yang paling dominan digunakan oleh masyarakat peternak sapi di Kecamatan Barebbo adalah bagi hasil berdasarkan laba kotor. Sistem ini dipandang lebih adil dan memberikan mashlahah kepada kedua belah pihak. Sistem ini dapat meningkatkan ekonomi masyarakat peternak di Kecamatan Barebbo Kabupaten Bone.

Kata Kunci: Bagi Hasil, Peternakan Sapi, Sosial Ekonomi, Peternak. 
Sitti Nikmah Marzuki:Prakterk Bagi Hasil Peternakan...

\section{PENDAHULUAN}

Islam adalah agama yang yang universal yang mengatur berbagai aspek kehidupan, baik sosial, ekonomi dan politik maupun kehidupan yang bersifat spiritual. Sebagai agama yang komprehensif, maka perilaku manusia diatur dengan atuaran akidah, akhlak dan muamalah. Melalui jalan muamalah, manusia dapat mengoptimalkan kemampuan yang dimiliki masing-masing untuk memenuhi kebutuhan hidupnya. Manusia dalam memenuhi kebutuhan hidupnya dengan bekerja dalam pandangan islam dinilai sebagai ibadah, selain memperoleh mataerial juga memperoleh pahala.

Sekarang ini, dalam hal pemenuhan kebutuhan banyak cara yang dapat dilakukan selama mengikuti koridor yang telah ditentukan oleh syariat. Salah satunya dengan menggunakan sistem kerja sama (syirkah), baik dalam prakteknya di dunia perbankan maupun dalam usaha produktif.

Sistem bagi hasil yang merupakan salah satu bentuk kerja sama antara pihak penyedia dana dan pengelolah dengan perjanjian keuntungan yang disepakati oleh kedua belah pihak. Islam memberikan jalan untuk mempermudah manusia yang memiliki kekurangan dana dengan melakukan kerja sama dengan pihak memiliki kelebihan dana. Baik secara perorangan maupun antara individu dengan jalan mudharabah.

Praktik mudharabah yang banyak dilakukan oleh masyarakat di Kabupaten Bone adalah bagi hasil peternakan sapi yang tersebar di beberapa desa di Kecamatan Barebbo. Pada pelaksanaannya, sering terjadi permasalahan yang muncul karena sistem bagi hasil yang tidak jelas, seperti halnya jika terjadi peristiwa force major pada saat perjanjian bagi hasil. Misalnya terjadi kematian terhadap anak sapi dari hasil peternakan sapi atau induknya sapi yang mengalami kematian. Pada kondisi ini selalu ada pihak yang dirugikan, baik dari pemilik modal maupun si pemelihara sapi (Asdar, 2017).

Selain itu masalah yang sering muncul adalah kelalaian dari pengelola sapi sehingga pemilik modal mengalami kerugian, karena sapi yang dipelihara tidak diberikan pakan yang cukup dibanding dengan sapi yang dimiliki oleh si pengelola 
Islamiconomic: Jurnal Ekonomi Islam

Vol.10 No.1 Januari - Juni 2019

sapi. Serta kerugian yang ditanggung jika ternyata sapi yang dipelihara mengalami kemandulan (Mamma Dg. Situru, 2017).

Berangkat dari latar belakang permasalahan tersebut, maka peneliti ingin mengetahui lebih mendalam lagi bagaimana praktek bagi hasil peternakan sapi di kecamatan Barebbo Kabupaten Bone dan memberikan pemahaman kepada masyarakat daerah tersebut berkaitan dengan akad mudharabah matteseng sapi dalam bentuk kontrak tertulis, untuk meminimalisir terjadi sengketa di masa mendatang.

\section{PEMBAHASAN}

Sistem bagi hasil merupakan sistem dimana dilakukannya perjanjian atau ikatan usaha bersama dalam melakukan kegiatan usaha. Di dalam usaha tersebut dibuat perjanjian adanya pembagian hasil atas keuntungan yang akan didapat antara kedua belah pihak atau lebih. Bagi hasil dalam sistem perbankan syariah merupakan ciri khusus yang ditawarkan kepada masyarakat, dan di dalam aturan syari'ah yang berkaitan dengan pembagian hasil usaha harus ditentukan terlebih dahulu pada awal terjadinya kontrak (akad). Besarnya penentuan porsi bagi hasil antara kedua belah pihak ditentukan sesuai kesepakatan bersama, dan harus terjadi dengan adanya kerelaan di masing-masing pihak tanpa adanya unsur paksaan. Mekanisme bagi hasil meliputi profit sharing dan revenue sharing.

Untuk mengatasi ketidaksetujuan prinsip profit sharing karena adanya kerugian bagi pemilik dana maka prinsip revenue sharing dapat diterapkan, yaitu bagi hasil yang di distribusikan kepada pemilik dana didasarkan pada revenue pengelola dana tanpa dikurangi dengan beban usaha untuk mendapatkan pendapatan. Dalam revenue sharing, kedua belah pihak akan selalu mendapatkan bagi hasil, karena bagi hasil dihitung dari pendapatan pengelola dana. Sepanjang pengelola dana memperoleh revenue maka pemilik dana akan mendapatkan bagi hasilnya. Tetapi bagi pengelola dana hal ini dapat memberikan risiko bahwa suatu periode tertentu pengelola dana mengalami kerugian, karena bagi hasil yang diterimanya lebih kecil dari beban usaha untuk mendapatkan revenue tersebut. Di sinilah ketidakadilan dapat dirasakan oleh pengelola dana karena terdapat resiko kerugian, sedangkan pemilik dana terbebas dari risiko kerugian. 
Sitti Nikmah Marzuki:Prakterk Bagi Hasil Peternakan...

Berdasarkan uraian di atas nampak perbedaan mendasar yang membedakan antara kedua prinsip tersebut. Pada prinsip profit sharing pendapatan yang akan dibagi adalah pendapatan bersih setelah pengurangan jumlah keseluruhan biaya terhadap total revenue. Sedang dalam prinsip revenue sharing pendapatan yang akan dibagi adalah pendapatan kotor dari penyaluran dana, tanpa harus dikalkulasikan terlebih dahulu dengan biaya-biaya pengeluaran operasional usaha. Kemudian pada prinsip profit sharing, biaya-biaya operasional akan dibebankan kedalam modal usaha atau pendapatan usaha, artinya biaya-biaya akan ditanggung oleh shahibul maal. Sedangkan dalam prinsip revenue sharing, biaya biaya akan ditanggung mudharib, yaitu pengelola modal.

Pada dasarnya syarikah dapat berbentuk syarikah hak milik (syirkah al-amlak) atau syirkah transaksi (syirkah al-'uqud). Syarikah hak milik adalah syarikah terhadap zat barang seperti syarikah dalam suatu zak barang yang diwarisi oleh dua orang, atau yang menjadi pembelian mereka atau hibah yang diberikan kepada mereka, maupun yang lainnnya. Adapun syarikah transaksi, karena yang menjadi objek adalah pengembangan hak milik. Syarikah transaksi bisa diklasikafikasikan menjadi lima macam yaitu; Syarikah 'Inan, adalah syarikah diantara dua orang atau lebih, masingmasing pihak berinvestasi dan secara bersama-sama mengelolah modal yang terkumpul dengan kesepakatan bahwa keuntungan dan resiko kerugian akan ditanggunhg bersama. Syarikah 'Abdan adalah syarikah antara dua orang atau lebih dengan masing-masing pihak hanya memperserokan badan mereka tanpa disertai investasi modal. Syarikah mudharabah adalah syarikah yang terbentuk antara dua pihak, pihak pertama menyediakan keseluruhan modal (shahibul mal) dan pihak lainnya menjadi pengelolah (mudharib). Syarikah wujuh; terdapat dua jenis syarikah wujuh yang dibenarkan oleh Islam. Pertama, berupa syarikah antara dua orang pengelolah atau lebih yang modalnya berasal dari pihak diluar kedua pengelolah tersebut. Ditinjau dari secara keseluruhan, syarikah ini masih tergolong syarikah mudharabah. Kedua, syarikah anatara dua orang atau lebih yang memiliki reputasi atau kepercayaan yang baik.

Syarikah mufawadah adalah syarikah antara dua persero atau lebih sebagai gabungan semua bentuk syarikah yang telah disebutkan di atas (Ismail Yusanto dan M. Arif Yunus, 2009). 
Islamiconomic: Jurnal Ekonomi Islam Vol.10 No.1 Januari - Juni 2019

Bentuk kerjasama di atas banyak digunakan dalam kehidupan sehari-hari, khususnya syirkah inan dan syirkah mudharabah dengan berbagai jenis usaha yang dijalankan oleh masyarakat. Secara bahasa mudharabah berasal dari kata Adh-dharbu fil ardh yaitu bepergian untuk urusan dagang. Disebut juga qiradh yang berasal dari kata al-qardhu yang berarti al-qath'u (potongan), karena pemiik memotong sebagian hartanya untuk diperdagangkan dan memperoleh sebagian keuntungannya. Maksudnya adalah akad antara kedua belah pihak untuk salah seorangnya (salah satu pihak) mengeluarkan sejumlah uang kepada pihak lainnya untuk diperdagangkan. Dan laba dibagi dua sesuai dengan kesepakatan (Sayyid Sabiq,, tth).

Para fuqoha memandang mudharabah dari akar kata ini dengan merujuk kepada pemakaiannya dalam Al-Qur'an yang selalu disambung dengan kata depan " $f i$ " kemudian dihubungkan dengan "al-ardh" yang memiliki pengertian berjalan di muka bumi. Mudharabah atau qiradh yang merupakan salah satu bentuk transaksi akad yang merupakan salah satu bentuk akad syirkah (perkongsian). Istilah mudharabah digunakan oleh orang Irak, sedangkan orang Hijaz menyebutnya dengan istilah qiradh (potongan) (Rachmat Syafi'i, 2004).

Berdasarkan pengertian diatas, maka dapat dipahami bahwa Mudharabah adalah jenis kontrak kerja sama antara dua pihak, salah satu pihak memberikan modal secara keseluruhan kepada pengelolah untuk dikelolah dan keuntungan dan kerugian dibagi bersama sesuai dengan kesepakatan.

Secara umum kegiatan mudharabah lebih mencerminkan anjuran untuk melaksanakan usaha. Hal ini ulama fiqih sepakat bahwa Mudharabah di syaratkan dalam Islam berdasarkan pada Al-Qur'an, Sunnah, Ijma' dan Qiyas. Akad mudharabah diperbolehkan dalam Islam, karena bertujuan untuk saling membantu antara pemilik modal dan seseorang yang ahli mengelolah uang (usaha/dagang). Adapun ayat-ayat yang berkenaan dengan mudharabah, antara lain Qs. Al-Muzammil ayat 20:

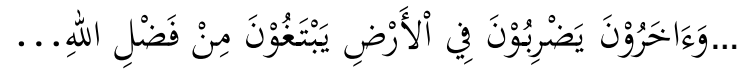

Artinya: ...Dan dari orang-orang yang berjalan di muka bumi mencari sebagian karunia Allah SWT...”

Berdasarkan ayat di atas, kata yadhribun yang sama dengan akarnya mudharabah yang berarti melakukan suatu perjalanan usaha. Mengandung arti untuk 108 
Sitti Nikmah Marzuki:Prakterk Bagi Hasil Peternakan...

melakukan usaha dengan melakukan perjalanan dimuka bumi untuk mencari karunia. Kemudian pada surat Al-Jumu'ah ayat 10:

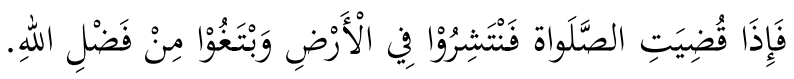

Artinya: "....apabila telah ditunaikan sholat, maka bertebaranlah kamu di muka bumi ini dan carilah karunia Allah SWT.

Di antara hadits yang berkaitan dengan mudharabah sebagaimana hadits yang diriwayatkan oleh ibn Majah dan Shuhaib bahwa Nabi SAW, bersabda:

$$
\begin{aligned}
& \text { عن صحيب أن النبي ص م قال :ثلا ث فيهن البركة : البيع الى أجل والمقارضة وخلط البر } \\
& \text { بالشعير للبيت لا للبيع (رواه ابن ماجه باسناد ضعيف) }
\end{aligned}
$$

Artinya: "Dari Shuhaib, adalah bahwasannya Rasulullah SAW berkata :"Tiga perkara yang mengandung berkah, yaitu jual-beli yang ditangguhkan, melakukan qiradh (memberi modal pada orang lain), dan yang mencampurkan gandum dengan jelas untuk keluarga, bukan untuk diperjualbelikan." (HR.Ibn Majah dan Shuhaib). (Ibnu Hasan Al-Asqalani, 1988).

Hadis di atas dapat dipahami bahwa Allah SWT memberikan berkah kepada pihak yang sedang bekerja sama selama mereka tidak melakukan pengkhianatan, manakala berkhianat bisnisnya akan tercela dan keberkahan pun akan sirna dari padanya.

Transformasi sektor pertanian ke sektor industri bagi negara sedang berkembang seperti Indonesia ini, tidaklah dapat dihindarkan. Karena Indonesia beranjak dari negara agraris menuju negara industri yang maju, maka peranan sektor pertanian masih tetap mewarnai kemajuan sektor industri, karena itulah diperlukan suatu kondisi struktur ekonomi yang seimbang antara bidang industri yang kuat dengan dukungan pertanian yang tangguh (Soekartawi dalam Ita Puspita Sari, 2014).

Peternakan sapi potong merupakan suatu industri di bidang agribisnis dengan rantai kegiatannya tidak hanya terbatas pada kegiatan on farm, tetapi juga meluas hingga kegiatan di hulu dan hilir sebagai unit bisnis pendukungnya. Di hulu, produksi bibit, pakan, sapronak merupakan kegiatan besar yang sangat mendukung 
Islamiconomic: Jurnal Ekonomi Islam

Vol.10 No.1 Januari - Juni 2019

tercapainya produktivitas sapi potong yang hebat, sementara di hilir, penanganan pascapanen memegang peranan yang sangat kuat untuk meningkatkan kualitas dan nilai tambah (value added) bagi daging sapi. Kegiatan-kegiatan tersebut perlu dilakukan secara integritas agar terbentuk sistem industri peternakan sapi potong yang kuat.

Tata laksana dan cara pemeliharaan ternak yaitu cara pemeliharaan intensif, pemeliharaan ekstensif dan pemeliharaan semiintensif (Rianto dan Purbowati dalam Ita Puspita Sari, 2014) yaitu; pertama pemeliharaan secara ekstensif. Pemeliharaan sapi secara ekstensif biasanya terdapat di daerah-daerah yang mempunyai padang rumput luas seperti di Nusa Tenggara, Sulawesi Selatan dan Aceh. Sepanjang hari sapi digembalakan di padang penggembalaan, sedangkan pada malam hari sapi hanya dikumpulkan di tempat-tempat tertentu yang diberi pagar, disebut kandang terbuka. Pada pemeliharaan secara ekstensif, kandang hanya digunakan untuk berlindung pada saat-saat tertentu saja (berfungsi secara parsial), yaitu pada malam hari dan saat-saat istirahat. Bahkan pada sistem pemeliharaan ini, kadang-kadang kandang tidak ada sehingga ternak hanya dapat berlindung di bawah pohon yang ada di padang penggembalaan tersebut. Kedua, Pemeliharaan secara intensif yaitu ternak dipelihara secara terus menerus di dalam kandang sampai saat dipanen sehingga kandang mutlak harus ada. Seluruh kebutuhan sapi disuplai oleh peternak, termasuk pakan dan minum. Aktivitas lain seperti memandikan sapi juga dilakukan di dalam kandang. Ketiga, pemeliharaan secara semi-intensif. Pemeliharaan sapi semacam ini merupakan perpaduan antara kedua cara pemeliharaan diatas. Jadi, pada pemeliharaan sapi secara semi-intensif ini harus ada kandang dan tempat penggembalaan.

Dalam perjanjian sistem bagi hasil peternakan sapi, menurut Muhzi Penggaduhan ternak adalah keadaan dimana seseorang dapat memelihara ternak (sapi) yang diperoleh dari orang lain dengan disertai suatu aturan tertentu tentang pembiayaan dan pembagian hasilnya. Mereka yang memelihara ternak orang lain atau pihak lain dengan sistem menggaduh ini, selanjutnya disebut penggaduh (petani penggaduh), sedangkan di lain pihak adalah pemilik ternak. Lebih lanjut bahwa pada dasarnya pemilik ternak dibedakan dalam dua macam yaitu pemerintah dan non pemerintah, dengan demikian terdapat suatu perbedaan yang sangat pokok dalam 110 
Sitti Nikmah Marzuki:Prakterk Bagi Hasil Peternakan...

sistem pembagian hasilnya sehingga memberikan pengaruh yang berbeda pula terhadap pendapatan yang diperoleh petani penggaduh dalam satu satuan tertentu Muhzi dalam Ita Puspita Sari, 2014). Menurut Siswijono pada sensus pertanian menunjukkan bahwa penerapan persyaratan bagi hasil sangat bervariasi (Siswijono dalam Ita Puspita Sari, 2014). Bahkan dalam satu komunitas pun sering dijumpai penerapan persyaratan aturan sistem bagi hasil yang berbeda. Variasi yang dimaksud mencakup pembagian hasil serta pembagian biaya sarana produksi. Besarnya bagian bagi hasil untuk penggaduh juga beragam, misalnya, besarnya berkisar antara 1/4, 1/3, 1/2, 2/3 dari nilai pertambahan bobot badan selama pemeliharaan (Sinaga dan Kasryono, 2014). Sementara itu menurut Kusnadi Sistem bagi hasil dapat diterapkan dalam empat model yaitu (Kusnadi dalam Ita Puspita Sari, 2014): pertama, dengan sistem bagi hasil berdasarkan pendapatan (Revenue Sharing System, RSS) sistem bagi hasil yang berbasiskan pendapatan adalah sistem bagi hasil yang didasarkan pada pendapatan yang diperoleh sebelum dikurangi dengan biaya-biaya yang dikeluarkan dalam proses produksi. Model bagi hasil ini digunakan dengan beberapa pertimbangan yaitu, penerima modal yang akan merugikan pemberi modal, misalnya manipulasi laporan keuangan yang cenderung membesarkan biaya-biaya yang dikeluarkan untuk menghindari pembayaran bagi hasil dan antara penerima dengan pemberi modal belum terbentuk hubungan yang saling percaya.

Kedua, Sistem bagi hasil berdasarkan laba kotor (Gross Profit Sharing System, GPSS). Sistem bagi hasil yang berbasiskan laba kotor adalah sistem bagi hasil yang didasarkan pada pendatan yang diperoleh setelah dikurangi dengan biaya biaya variabel yang dikeluarkan dalam proses produksi. Model ini digunakan dengan pertimbangan adalah penerima dan pemberi modal dalam melakukan kerjasama terbentuk hubungan yang saling amanah (percaya).

Ketiga, sistem bagi berdasarkan laba operasi bersih (Operating Profit Sharing System, OPSS). Sistem bagi hasil yang berbasiskan laba operasi kotor adalah sistem bagi hasil yang didasarkan pendapatan yang diperoleh setelah dikurangi dengan biaya-biaya variabel dan biaya-biaya serta biaya lain. Model ini digunakan dengan pertimbangannya adalah antara penerima dam pemberi modal terbentuk hubungan yang saling amanah (percaya). 
Islamiconomic: Jurnal Ekonomi Islam

Vol.10 No.1 Januari - Juni 2019

Keempat, sistem bagi hasil berdasarkan laba bersih (Net Profit Sharing System, NPSS). Sistem bagi hasil yang berbasiskan laba bersih adalah sistem bagi hasil yang didasarkan pada pendapatan yang diperoleh setelah dikurangi dengan biaya-biaya variabel dan biaya-biaya tetap serta biaya-biaya lainnya dan telah dikurangi pajak yang harus di bayarkan. Model ini digunakan dengan pertimbangan antara penerima dan pemberi modal karena benar-benar telah saling percaya, transparan dan profesional.

\section{METODOLOGI PENELITIAN}

Pada penelitian ini, jika dilihat dari objek penelitiannya, maka penelitian ini adalah lapangan, kegiatan penelitian yang dilakukan di lingkungan masyarakat tertentu baik dilembaga-lembaga, organisasi masyarakat sosial maupun lembaga pemerintah (Suharsimi, 2005). Jenis Penelitian ini adalah penelitian kualitatif yaitu penelitian yang mengungkap dan menganalisis model bagi hasil peternakan sapi dan menganalisis konsep mashlahah dalam praktek bagi hasil matteseng sapi serta memformukasikan soluasi yang lebih adil dalam praktek matteseng sapi.

Pendekatan yang teologis normatif (syar'i). Pendekatan ini digunakan untuk menganalisis ketentuan-ketentuan fikih tentang model bagi hasil (mudharabah) peternakan sapi. Pendekatan sosiologi digunakan untuk menelaah perilaku sosial masyarakat dalam melakukan perjanjian dan menyelesaikan sengketa bagi hasil ternak sapi.

Sumber data yang digunakan dalam penelitian ini adalah terdiri dari data primer, yaitu data yang diperoleh dari sumber asli yang memuat informasi (Sutrisno Hadi, 1999). Sumber data primer ini meliputi wawancara dengan pengelola atau peternak sapi dan pihak pemilik sapi di Kecamatan Barebbo Kabupaten Bone. Dan data sekunder yaitu data yang diperoleh dari sumber yang bukan asli dan memuat informasi (Abudin Nata, 2003). Adapun data sekunder dalam penelitian ini adalah obeservasi perilaku pengelola sapi dalam menyelesaikan sengketa bagi hasil ternak sapi.

Untuk teknik pengumpulan data yang dilakukan digunakan peneliti dalam penelitian ini terdiri dari; Library research, yaitu data-data yang dikumpulkan melalui penulusuran literatur-literatur yang berhubungan dengan masalah yang dibahas 
Sitti Nikmah Marzuki:Prakterk Bagi Hasil Peternakan...

dalam penelitian ini. Field research, yaitu data-data yang dibutuhkan dan diperoleh dari lapangan dengan menggunakan teknik Observasi, yaitu peneliti secara langsung melihat dan mengamati. Selain itu, peneliti melakukan wawancara kepada responden untuk mendapatkan informasi dan data yang sebanyak-banyaknya atau setuntastuntasnya berkaitan dengan penelitian ini. Teknik analisis data yang digunakan untuk penelitian ini adalah menggunakan teknik analisis deskriptif kualititatif. Analisis deskriptif kualitatif yaitu analisis yang digunakan untuk menganalisis dan mendeskripsikan sistem bagi hasil peternakan sapi (matteseng) di Kecamatan Barebbo Kabupaten Bone dan mendeskripsikan tingkat ekonomi masyarakat Kecamatan Barebbo Kabupaten Bone serta memformukasikan solusi yang lebih adil dalam praktek matteseng di Kecamatan Barebbo Kabupaten Bone.

\section{PEMBAHASAN}

Kabupaten Bone adalah salah satu kabupaten terluas di Sulawesi Selatan. Kabupaten Bone memiliki 27 KecamataN. Sebagai kabupaten yang memiliki wilayah yang luas dan padang rumput yang luas memiliki potensi untuk melakukan berbagai usaha khususnya peternakan sapi.

Kecamatan Barebbo termasuk ke dalam wilayah Pemerintah Kabupaten Bone Propinsi Sulawesi Selatan. Wilayahnya merupakan hamparan laut, tanah datar, dan bukit dengan batas-batas wilayah administrasi antara lain: Sebelah Utara berbatasan dengan Kecamatan palakka, Tanete Riattang dan Tanete Riattang Barat. Sebelah Selatan berbatasan dengan Kecamatan Cina dan Kecamatan Sibulue. Sebelah Timur berbatasan dengan Kecamatan Sibulue dan Teluk Bone. Sebelah Barat berbatasan dengan Kecamatan palakka dan kacamatan Bengo.

Untuk lebih jelasnya dapat dilihat pada gambar di bawah ini yang menunjukkan peta Kecamatan Barebbo: 


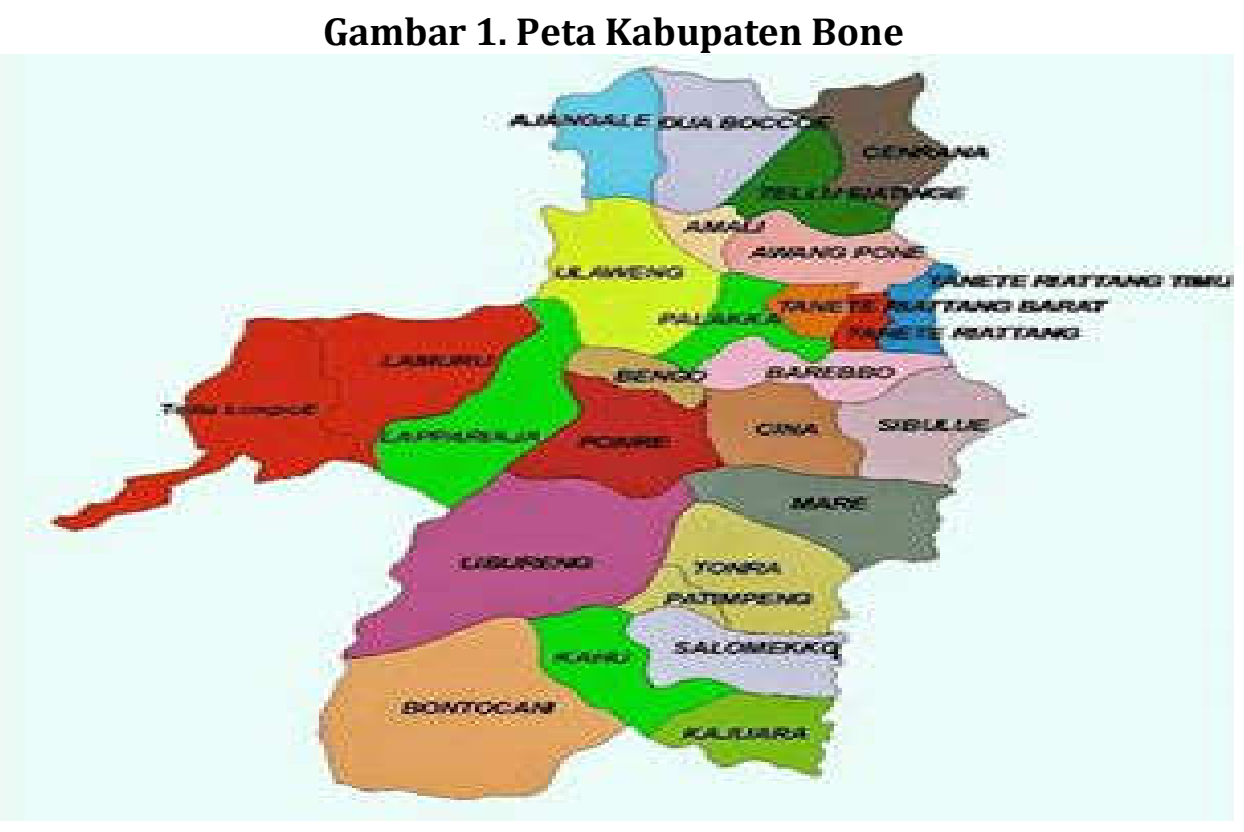

Kecamatan Barebbo dengan luas wilayah 114,21 km2 dan terdiri dari 18 Desa/Kelurahan. Kecamatan Barebbo termasuk daerah yang subur, wilayahnya terdiri dari lahan persawahan yang luas dan hamparan laut yang memiliki potensi hasil laut yang melimpah. Untuk lebih jelasnya mengenai nama dan luas wilayah kelurahan yang ada di Kecamatan Barebbo dapat dilihat pada tabel di berikut ini :

Tabel 1. Daftar Desa/Kelurahan di Kacamatan Barebbo Kabupaten Bone

\begin{tabular}{|c|l|c|}
\hline No. & \multicolumn{1}{|c|}{ Nama Desa/Kelurahan } & Luas Wilayah $\mathbf{( K m}^{\mathbf{}} \mathbf{)}$ \\
\hline 1. & Cempaniga & 190 \\
\hline 2. & Bacu & 166 \\
\hline 3. & Cingkang & 165 \\
\hline 4. & Congko & 95 \\
\hline 5. & Cinnong & 95 \\
\hline 6. & Lampoko & 166 \\
\hline 7. & Wollangi & 61 \\
\hline 8. & Kajaolaliddong & 47 \\
\hline 9. & Samaelo & 36 \\
\hline 10 & Parippung & 42 \\
\hline 11 & Apala & 40 \\
\hline 12 & Sugiale & 21 \\
\hline 13 & Kampuno & 14 \\
\hline
\end{tabular}


Sitti Nikmah Marzuki:Prakterk Bagi Hasil Peternakan...

\begin{tabular}{|c|l|c|}
\hline 14 & Corowali & 40 \\
\hline 15 & Talungeng & 19 \\
\hline 16 & Barebbo & 16 \\
\hline 17 & Watu & 11 \\
\hline 18 & Kading Total & 10 \\
\hline \multicolumn{2}{|c|}{} \\
\hline
\end{tabular}

Untuk melihat lebih jelas persebaran daerah di Kecamatan Barebbo dapat dilihat dari gambar berikut ini:

Gambar 4.2.

Peta Kecamatan Barebbo

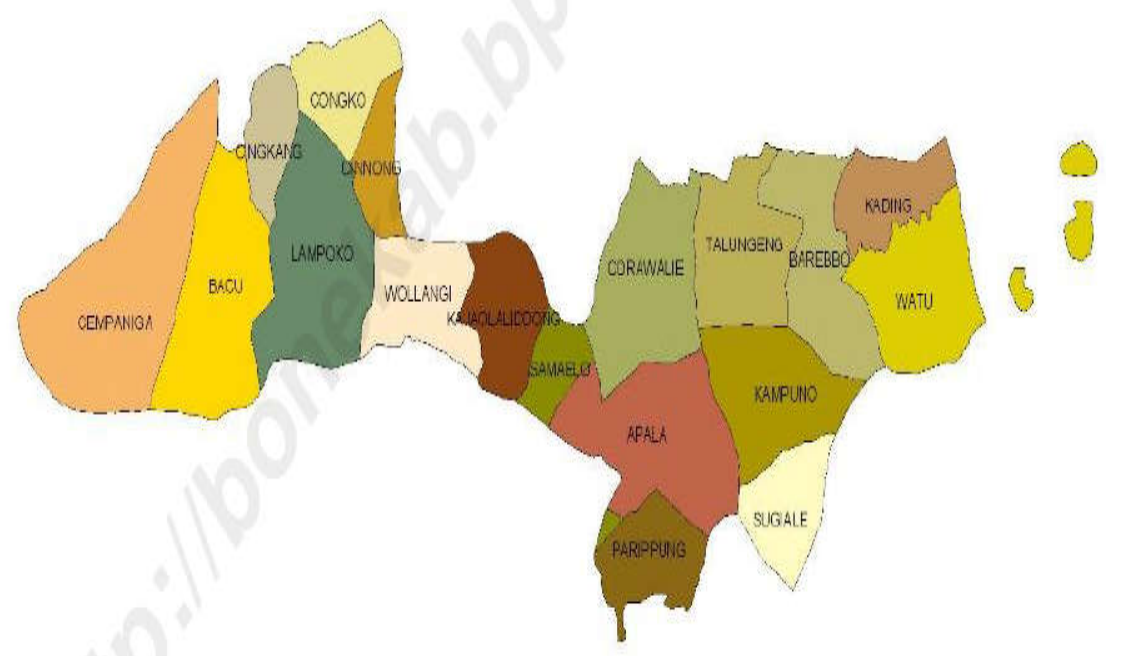

Sumber : BPS Kabupaten Bone

Kecamatan Barebbo yang terdiri dari 18 Desa/kelurahan adalah salah satu kecamatan yang memiliki daerah yang luas. Daerahnya yang luas memungkinan memiliki jumlah penduduk yang besar. Untuk memenuhi kebutuhan hidup masyarakatnya berbagai mata pencaharian yang dilakukan mulai menjadi petani, pedagang, pelaut hingga menjadi peternak.

\section{Jumlah Penduduk dan Mata Pencaharian Masyarakat Kecamatan Barebbo Kabupaten Bone}

Tabel 4.2.

Jumlah Penduduk Kecamatan Barebbo

Menurut Jenis Kelamin

\begin{tabular}{|c|l|c|c|c|}
\hline \multirow{2}{*}{ No. } & \multirow{2}{*}{ Desa/Kelurahan } & \multicolumn{2}{|c|}{ Jenis Kelamin } & \multirow{2}{*}{ Jumlah } \\
\cline { 3 - 4 } & & Laki-laki & Perempuan & \\
\hline 1. & Cempaniga & 219 & 228 & 447 \\
\hline 2. & Bacu & 480 & 536 & 1.016 \\
\hline
\end{tabular}


Islamiconomic: Jurnal Ekonomi Islam Vol.10 No.1 Januari - Juni 2019

\begin{tabular}{|c|l|c|c|c|}
\hline 3. & Cingkang & 265 & 270 & 535 \\
\hline 4. & Congko & 549 & 671 & 1.220 \\
\hline 5. & Cinnong & 240 & 273 & 513 \\
\hline 6. & Lampoko & 749 & 850 & 1.599 \\
\hline 7. & Wollangi & 319 & 398 & 717 \\
\hline 8. & Kajaolaliddong & 747 & 847 & 1.594 \\
\hline 9. & Samaelo & 752 & 898 & 1.650 \\
\hline 10. & Parippung & 510 & 616 & 1.126 \\
\hline 11. & Apala & 1.320 & 1.438 & 2.758 \\
\hline 12. & Sugiale & 584 & 693 & 1.277 \\
\hline 13. & Kampuno & 927 & 1.119 & 2.046 \\
\hline 14. & Corowali & 1.085 & 1.194 & 2.279 \\
\hline 15. & Talungeng & 588 & 683 & 1.271 \\
\hline 16. & Barebbo & 828 & 876 & 1.704 \\
\hline 17. & Watu & 1.062 & 1.223 & 2.285 \\
\hline 18. & Kading & $\mathbf{1 2 . 8 6 6}$ & $\mathbf{1 4 . 7 1 4}$ & $\mathbf{2 7 . 5 8 0}$ \\
\hline
\end{tabular}

\section{Sumber : Data BPS Tahun 2017}

Berdasarkan data diatas, maka dapat lihat bahwa jumlah penduduk Kecamatan Berebbo pada tahun 2017 berasarkan data Badan Pusat Statistik Kabupaten Bone sebanyak 27.580 jiwa yang terdiri dari 12.866 jiwa berjenis kelamin laki-laki dan sebanyak 14.714 jiwa berjenis kelamin perempuan.

\section{Data Peternakan di Kecamatan Barebbo Kabupaten Bone}

Tabel 4.3

Data Ternak Besar Di Kecamatan Barebbo Kabupaten Bone

\begin{tabular}{|c|c|c|c|c|c|c|}
\hline \multirow[t]{2}{*}{ No. } & \multirow[t]{2}{*}{ Desa/Kelurahan } & \multicolumn{4}{|c|}{ Ternak Besar (Ekor) } & \multirow[t]{2}{*}{ Ket. } \\
\hline & & Sapi & Kerbau & Kuda & Kambing & \\
\hline 1. & Cempaniga & 431 & 11 & 55 & & \\
\hline 2. & Bacu & 560 & 31 & 49 & & \\
\hline 3. & Cingkang & 341 & 20 & 35 & & \\
\hline 4. & Congko & 421 & 17 & 37 & & \\
\hline 5. & Cinnong & 312 & & 10 & & \\
\hline 6. & Lampoko & 569 & 29 & 46 & & \\
\hline 7. & Wollangi & 587 & 15 & 36 & & \\
\hline 8. & Kajaolaliddong & 327 & 12 & 33 & & \\
\hline 9. & Samaelo & 221 & 5 & 21 & & \\
\hline 10. & Parippung & 415 & 30 & 45 & 6 & \\
\hline 11. & Apala & 356 & 15 & 38 & 7 & \\
\hline 12. & Sugiale & 24 & & 12 & & \\
\hline 13. & Kampuno & 437 & 21 & 48 & 5 & \\
\hline 14. & Corowali & 312 & 10 & 30 & 12 & \\
\hline 15. & Talungeng & 281 & 5 & 23 & & \\
\hline 16. & Barebbo & 315 & 19 & 41 & 9 & \\
\hline
\end{tabular}


Sitti Nikmah Marzuki:Prakterk Bagi Hasil Peternakan...

\begin{tabular}{|c|l|c|c|c|c|c|}
\hline 17. & Watu & 217 & 4 & 31 & 57 & \\
\hline 18. & Kading & 215 & 7 & 37 & 41 & \\
\hline \multicolumn{2}{|c|}{ Barebbo } & $\mathbf{6 3 4 1}$ & $\mathbf{2 5 1}$ & $\mathbf{6 2 7}$ & $\mathbf{1 3 7}$ & $\mathbf{2 7 . 5 8 0}$ \\
\hline
\end{tabular}

Sumber : Data Kantor Kecamatan Barebbo Kabupaten Bone

Berdasarkan data diatas, dapat dilihat bahwa data kantor kecamatan Barebbo Kabupaten Bone Tahun 2017 menunjukkan bahwa jumlah ternak sapi lebih dominan dari pada ternak kuda, kerbau dan kambing. Pada tahun 2017 jumlah ternak sapi sebanyak 6.341 ekor ternak sapi yang terdiri dari sapi potong dan sapi ternak. Data ini menunjukkan bahwa Kecamatan Barebbo sebagai salah satu daerah yang menjadi penyedia ternak sapi di Kabupten Bone.

\section{Sistem Peternakan Sapi Masyarakat Kecamatan Barebbo Kabupaten Bone}

Kecamatan Barebbo yang terdiri dari 18 Desa/kelurahan menjadi salah satu daerah yang menghasilkan komediti ternak sapi di Kabupaten Bone.

1. Jenis Ternak Sapi

Peternakan sapi yang banyak ditekuni para peternak sapi di Kecamatan Barebbo didominasi dengan peternakan penggemukan dan peternakan anakan. Peternakan penggemukan dilakukan dengan cara pemilik sapi membeli sapi dengan harga tertentu dan diberikan kepada pihak pemelihara dengan jangka waktu tertentu hingga sapi tesebut memiliki bobot yang diinginkan dan kemudian dijual kembali dengan harga yang lebih tinggi (Hasan, 2017).

Disamping itu jenis yang lain yang sering dilakukan oleh masyarakat Kecamatan Barebbo adalah peternakan sapi pembiakan. Pemilik sapi membeli indukan sapi untuk dipelihara oleh si pengelola untuk kemudian dikembangbiakan. Kemudian dilakukan proses pembiakan dengan sapi jantan baik yang disediakan oleh pemilik sapi maupun si pengelolah, sesuai dengan kesepakatan masing-masing. Jika induk sapi masih dalam usia produktif dan tidak pernah melahirkan sebelumnya, maka anak pertama dari hasil pembiakan menjadi milik si pemilik sapi dan anak kedua menjadi milik si pengelola. Namun jika induk sapi sudah pernah melahirkan sebelumnya, maka anak pertama dari hasil pembiakan milik si pengelola dan anak kedua menjadi milik si pemilik sapi.

2. Cara Peternakan Sapi

Ada tiga cara yang umum digunakan peternak sapi dalam proses pemeliharaan sapi yaitu:

\section{a. Pemeliharaan Secara Ekstensif}

Pemeliharaan sapi secara ekstensif biasanya terdapat di daerah-daerah yang mempunyai padang rumput luas seperti di Nusa Tenggara, Sulawesi Selatan dan Aceh. Sepanjang hari sapi digembalakan di padang penggembalaan, sedangkan pada malam hari sapi hanya dikumpulkan di tempat-tempat tertentu yang diberi pagar, disebut kandang terbuka. Pada pemeliharaan secara ekstensif, kandang hanya digunakan untuk berlindung pada saat-saat tertentu saja (berfungsi secara parsial), yaitu pada malam hari dan saat-saat istirahat. Bahkan pada sistem pemeliharaan ini, kadang-kadang kandang tidak ada sehingga ternak hanya dapat berlindung di bawah pohon yang ada di padang penggembalaan tersebut. 
Islamiconomic: Jurnal Ekonomi Islam

Vol.10 No.1 Januari - Juni 2019

Berdasarkan hasil wawancara dengan Informan bahwa sebahagian besar peternak sapi di Kecamatan Barebbo Khususnya di Desa Lampoko, Desa Wollangi menggunakan sistem pemeliharaan ekstensif karena kondisi alam di daerah tersebut menyediakan padang rumput yang luas, sehingga sapi di lepas untuk kemudian mencari sendiri makan di padang rumput. (Hasan, 2017). Namun Jika musim kemarau tiba, maka peternak menggunakan pakan dari dedak. Ini menambah biaya pemeliharaan peternak, dedak biasanya dijual dengan harga Rp. 3.000,- perliternya. Sehingga peternak sapi harus mengeluarkan biaya tambahan pada saat kemarau.

Namun sistem pemeliharaan ini memiliki kekurangan, biasanya peternak sering mendapat masalah ketika terjadi pencurian ternak, ternak yang dibiarkan di alam bebas memiliki resiko kehilangan, baik kehilangan disebabkan ternak yang meninggalkan tempat atau ladang yang biasa ditinggali, maupun resiko kehilangan oleh pencuri ternak. Untuk meminimalisir pemerintah daerah khusunya di desa melakukan pengawasan dan mengingat hewan ternak di sore hari agar tidak meninggalkan tempat dan melepaskan kembali di pagi hari agar sapi -sapi tersebut mencari makan sendiri di alam bebas.

b. Pemeliharaan secara intensif

Pemeliharaan secara intensif yaitu ternak dipelihara secara terus menerus di dalam kandang sampai saat dipanen sehingga kandang mutlak harus ada. Seluruh kebutuhan sapi disuplai oleh peternak, termasuk pakan dan minum. Aktivitas lain seperti memandikan sapi juga dilakukan di dalam kandang.

Pemeliharaan ini dilakukan dengan berbagai pertimbangan, diantaranya sapi akan lebih aman dari pencurian ternak dan ternak tidak akan merusak hasil pertanian masyararakat. Pemeliharaan sapi dengan cara ini pada umumnya di daerah yang hampir tidak memiliki padang rumput. Daerah yang memiliki lahan persawahan, sehingga di musim tanam sapi tidak dapat dibiarkan berkeliaran karena berpotensi merusak lahan pertanian. Masyarakat lebih cenderung memberikan rumput gajah yang sudah ditanam oleh peternak atau bahkan menyiapkan pakan ternak berupa dedak.

Umumnya daerah yang menggunakan sistem ini adalah daerah yang memiliki musim panen 3 kali setahun, maka proses bercocok tanam di sawah dilakukan secara terus menerus. Sehingga aktivitas di sawah tidak terhenti. Maka peternak harus mengandangkan sapi mereka agar tidak merusak lahan pertanian.

Sistem pemeliharaan ini tentunya membutuhkan biaya pemeliharaan yang lebih besar, peternak harus menyediakan kandang dan pakan. Setiap harinya peternak harus menyediakan pakan baik rumput gajah maupun dengan dedak. Pemberian pakan 2 kali sehari demikian pula dengan air.

c. Pemeliharaan secara semiintensif

Pemeliharaan sapi secara semiintensif merupakan perpaduan antara kedua cara pemeliharaan diatas. Jadi, pada pemeliharaan sapi secara semiintensif ini harus ada kandang dan tempat penggembalaan.

Umumnya sistem ini digunakan di daerah pegunungan yang memiliki cukup rumput dan pemilik sapi juga menginkan keamanan untuk ternaknya, sehingga setiap pagi dan sore hari mereka akan mengeluarkan dan memasukkan sapi ternak ke kandangnya. Pada saat tertentu, ketika alam menyediakan rumput yang berlimpah, maka peternak sapi membiarkan sapi mereka untuk memakan rumput 
Sitti Nikmah Marzuki:Prakterk Bagi Hasil Peternakan...

dan ketika musim panen telah berlalu, sapi kemudian digembalakan di lahan persawahan untuk mencari makan dari sisa-sisa jerami. Ini umumnya dilakukan di daerah yang memiliki padang rumput dan area persawahan yang memiliki masa panen yang 2 kali dalam setahun. Berbeda dengan daerah yang memiliki musim panen 3 kali setahun.

Pendapatan Masyarakat Peternak Sapi di Kecamatan Barebbo Kabupaten Bone

Masyarakat Kecamatan barebbo umumnya adalah pertanian dan peternakan. Mata pencaharian inilah yang dominan ditekuni oleh masyarakat setempat. Dikenal sebagai daerah yang memiliki padang rumput dan persawahan memungkinkan ketersediaan pakan untuk ternak sapi. Sehingga daerah ini menjadi salah satu pemasok daging sapi di Kabupaten Bone.

Peternak sapi di Kecamatan Barebbo ditekuni oleh kaum laki-laki dan perempuan. Dari hasil observasi yang dilakukan dan wawancara mendalam proses pemeliharaan sapi melibatkan laki-laki dan perempuan, meskipun masih didominasi oleh laki-laki.

Laki-laki sebagai kepala rumah tangga memiliki tanggung jawab untuk memberikan nafkah kepada keluarga. Melalui kerjasama peternakan sapi, sedikit banyak memberikan pendapatan kepada masyarakat. Pada umumnya peternak sapi memiliki pekerjaan yang lain, seperti seorang petani.

Selain itu, banyak peternak sapi yang memiliki pekerjaan ganda. Pekerjaan sebagai peternak dilakukan setelah pekerjaan utama selesai. Ada peternak sapi yang bekerja kantoran, namun disamping itu memiliki ternak sapi sebagai penghasilan tambahan. Hasil dari ternak sapi ini digunakan untuk memenuhi kebutuhan sekundernya( Nurdin Hasan, 2017).

Terkait dengan pendapatan yang diperoleh oleh peternak sapi dari hasil kerjasama peternakan sapi, dari 18 informan yang dilakukan wawancara dan observasi, para peternak memiliki beberapa perbedaan penghasilan. Untuk lebih jelasnya dapat dilihat pada tabel berikut ini:

Tabel 4.4.

Pendapatan Peternak Sapi

\begin{tabular}{|r|c|c|}
\hline No. & Pendapatan (Rupiah) & $\begin{array}{c}\text { Jumlah Peternak } \\
\text { (Orang) }\end{array}$ \\
\hline 1. & $1.000 .000-2.000 .000$ & - \\
2. & $2.000 .001-3.000 .000$ & 5 \\
3. & $3.000 .001-4.000 .000$ & 6 \\
4. & $4.000 .001-5.000 .000$ & 4 \\
5. & $>5.000 .000$ & 3 \\
\hline
\end{tabular}

Berdasarkan hasil observasi dan tabel diatas, maka dapat dilihat bahwa pendapatan peternak sapi umumnya masih berkisar Rp. 2.000.000 - Rp. 5.000.000 setiap satu ekor sapi tergantung dari kondisi sapi dan teknik bagi hasil yang disepakati. Jika peternak melakukan kerjasama ternak sapi 2 sapi maka peternak akan memiliki keuntungan yang lebih besar.

Berdasarkan hasil wawancara yang dilakukan dengan beberapa informan peternak sapi dan pihak pemilik sapi, sejak masyarakat menerapkan sistem bagi hasil pada ternak sapi, maka masyarakat peternak mendapatkan pendapatan tambahan, yang umumnya peternak juga bekerja sebagai petani. Peternak yang memiliki pekerjaan 
Islamiconomic: Jurnal Ekonomi Islam

Vol.10 No.1 Januari - Juni 2019

ganda sebagai petani, ketika tiba masa tanam, sapi dikandangkan dan lebih fokus pada usaha pertaniannya, namun jika masa panen berakhir, maka sapi akan mendapat pakan yang melimpah dari hasil limbah panen di sawah. Pada saat ini peternak akan lebih mudah menyediakan pakan ternak.

Bahkan peran perempuan juga tidak kalah penting, biasanya para perempuan membantu dalam proses penyedian pakan ternak, menyediakan minum dan pembersihan kandang. Kerja sama antara keduanya mempermudah kerja peternak, dapat melakukan pekerjaan dalam waktu yang bersamaan menjadi petani dan peternak.

\section{Model Pengembangan Bagi Hasil Peternakan Sapi Masyarakat Kecamatan Barebbo Kabupaten Bone.}

Sistem bagi hasil ternak sapi di Kecamatan Barebbo pada dasarnya berlaku berdasarkan tradisi masyarakat yang sudah turun temurun dilakukan. Namun sesuai dengan perkembangan pengetahuan masyarakat dengan mempertimbangkan berbagai hal, maka pola-pola lama mengalami perkembangan. Sebagai kecamatan penghasil ternak sapi, kecamatan Barebbo menjadi salah satu wilayah yang dijadikan tempat untuk memenuhi kebutuhan masyarakat kabupaten Bone khususnya ternak sapi. Harga sapi akan mengalami peningkatan pada masa-masa tertentu khususnya pada saat musim kurban.

Pada umumnya masyakarat kecamatan Barebbo yang tersebar di 18 Desa mengamali perkembangan dan menggunakan 2 sistem bagi hasil. Ketiga sistem itu masing-maing dilakukan dibeberapa desa.

1. Jenis Perjanjian Ternak Sapi

Oleh karena itu, banyak masyarakat yang memiliki dana kemudian bekerja sama dengan peternah untuk melakukan kerja sama baik dengan pembiakan maupun bagi hasil. Berdasarkan hasil observasi dan wawancara yang dilakukan oleh peneliti di Kecamatan Barebbo, ada 2 jenis perjanjian bagi hasil yang dilakukan oleh masyarkat yaitu sebagai berikut:

a. Perjanjian Hasil Ternak (Teseng)

Perjanjian ini banyak dilakukan oleh masyarakat peternak yang tidak memiliki modal untuk membeli sapi, sehingga pemilik sapi mempercayakan kepada peternak untuk melakukan pemeliharaan dan pembiakan sapi.

Kebiasaan ini sudah menjadi tradisi masyarakat di Kecamatan Barebbo. Kebiasaan ini menurut penulis adalah keliru karena kemungkinan jika perjanjian bagi hasil yang tidak dilakukan secara tertulis memungkinkan terjadinya kesalahan pada saat pelaksanaan perjanjian. Hal ini bisa memungkinkan terjadinya kecurangan pada salah satu pihak.

Kecurangan yang mungkin terjadi, jika pemilik sapi tidak melakukan kontrol secara berkala, maka peternak sapi yang tidak ulet, maka sapi yang dipelahara tidak akan produktif.

Sistem bagi hasil ini adalah yang masih banyak berkembang di masyarakat, sistem ini dianggap paling mudah dilakukan oleh masyarakat dan sudah dikenal. Pemilik sapi memberikan kuasa kepada peternak untuk memelihara sapi dengan memberi pakan hingga mengusahakan sapi untuk berkembang biak. Biaya yang dikeluarkan ditanggung oleh peternak. Praktek konvensional ini yang lebih dominan digunakan oleh masyarakat di Kecamatan Barebbo meskipun dibeberapa desa sudah melakukan pengambangan sistem bagi hasil. 
Sitti Nikmah Marzuki:Prakterk Bagi Hasil Peternakan...

Namun disisi lain, sistem ini sudah mulai ditinggalkan masyarakat karena banyak mengandung kerugian. Baik peternak maupun pemilik sapi. Jika selama proses pemeliharaan dan anak sapi mengalami kematian atau sejenisnya, maka hanya salah satu pihak yang akan menanggung kerugian (Nurfadillah, 2018).

Sistem ini banyak dilakukan di Desa Wollangi, Desa Kajaolaliddong, Congko dan Barebbo. Sapi yang telah diberikan pemilik sapi untuk dipelihara peternak, disertai dengan perjanjian antara dua belah pihak. Umumnya masyarakat melakukan perjanjian secara lisan, tidak menuliskan perjanjian bagi hasil ternak sapi dalam bentuk kontrak tertulis.

Sistem bagi hasil anak prakteknya dengan cara pemilik sapi menyiapkan induk sapi yang kemudian dikembangbiakkan oleh peternak dengan cara kawin suntik maupun menggunakan sapi jantan. Hasil perkembang biakannya kemudian dibagi berdasarkan kesepakatan antara pemilik sapi dan peternak sapi.

Bagi hasil yang diterapkan yaitu jika induk sapi belum pernah melahirkan maka, jika induk sapi melahirka//n anak, maka menjadi hak si peternak sapi. Berbeda halnya jika induk sapi telah memiliki anak sebelumnya, maka anak yang lahir pertama menjadi hak pemilik sapi. Ini umumnya dilakukan oleh masyarakat khususnya di Desa Lampoko, Congko, Kajaolaliddong, Wollangi, Cinnong, Sugiale, Barebbo dan Kading.

Perkembangan sistem bagi hasil selanjutnya terjadi di beberapa desa seperti di Desa Watu, umumnya masyarakat telah mengubah sistem bagi hasil berbagi anak. Mereka melakukan perubahan sistem bagi hasil karena sistem sebelumnya dianggap banyak mengandung kerugian (Hasmadianto, 2018).

Pada prakteknya, seiring kebutuhan masyarakat akan dana yang lebih instant dan perubahan pola pikir di sebahagian masyarakat sistem yang sebelumnya dengan bagi hasil anak mengalami perkembangan. Salah satu desa yang mengalami perkembangan demikian di Desa Watu, sistem yang diterapkan dengan cara si pemilik membeli induk sapi untuk dipelihara oleh peternak sapi. Sapi kemudian dikembangbiakkan baik menggunakan sistem kawin suntik maupun menggunakan sapi jantan. Jika induk telah memiliki anak, maka anak sapi dipelihara hingga dewasa dan kemudian dijual, dari hasil penjualan sapi dibagi berdasarkan kesepakatan. Contoh jika sapi terjual dengan harga Rp. 9.000.000, maka dibagi dua, maka masing-masing pihak mendapatkan keuntungan Rp. 4.500.000 (Halide, 2018).

Berdasarkan hal di atas, dapat dipahami bahwa pengembangan sistem bagi hasil dengan sistem bagi hasil penjualan anakan sapi lebih baik dari sistem bagi hasil anak yang sudah dilakukan secara turun temurun. Sistem bagi hasil ini cenderung meminimalisir terjadi kerugian dari salah satu pihak. Jika sapi mengalami kematian, maka kedua belah pihak berbagi kerugian. Namun jika sapi mengalami kematikan dikarenakan oleh pihak peternak yang lalai, barulah dibicarakan penyelesainya.

Sistem ini lebih adil, baik pemilik sapi dan peternak sapi sama-sama bisa mendapatkan hasil dengan cepat. Kerugian yang terjadi jika anak sapi mengalami kematian tidak hanya ditanggung oleh salah satu pihak. Dengan sistem ini peternak juga akan lebih fokus memelihara ternak sapi, karena semakin sehat sapi yang dipelihara dan semakin gemuk akan mempengaruhi harga jual sapi. Harga 
Islamiconomic: Jurnal Ekonomi Islam

Vol.10 No.1 Januari - Juni 2019

jual sapi yang tinggi memungkinkan peternak dan pemilik sapi untuk mendapatkan hasil yang lebih besar.

Lebih lanjut praktek bagi hasil ini meminimalisir kecurangan peternak. Peternak akan lebih berhati-hati dan berusaha untuk memberikan pakan terbaik untuk sapi, karena sapi menjadi hak bersama. Jika sapi berkembang dengan baik dan sehat maka pastinya akan memiliki harga jual yang lebih tinggi.

Berbeda hal dengan sistem anakan sapi, jika peternak memiliki karakter jujur dan bertanggung jawab, maka kemungkinan kecurangan tidak terjadi. Namun tidak dipungkiri masih banyak peternak yang memiliki karakter yang tidak jujur dan bertanggung jawab. Anak sapi dari hasil perjanjian bagi hasil (teseng) dipelihara oleh peternak, baik yang menjadi hak peternak maupun pemilik sapi, jika si peternak berbuat curang memelihara dan memberikan pakan pada ternak yang menjadi miliknya dan ternak milik pemodal dipelihara seadanya, sehingga kualitas sapi pemilik dan peternak akan berbeda, maka terjadi kezaliman dan ketidakadilan antara pemilik dan peternak.

b. Perjanjian Bagi Hasil/Penggembukan Sapi

Sistem bagi hasil penggemukan banyak dilakukan di Kecamatan Barebbo, dengan pertimbangan bahwa cara ini memungkinkan peternak dan pemilik sapi mendapat hasil lebih cepat dari pada hanya menunggu anak sapi untuk siap dijual. Hampir disetiap desa di Kecamatan Barebbo menggunakan sistem bagi hasil ini.

Pada prakteknya, pemilik sapi akan mendapatkan hasil dari penjualan sapi tergantung harga jual sapi. Ada dua sistem yang berkembang pada masyarakat kecamatan Barebbo yang diterapkan dalam bagi hasil penggemukan.

Sistem yang pertama yaitu bagi hasil berdasarkan laba kotor. Pada pelaksanaannya, Pemilik sapi selaku pemodal membeli sapi untuk kemudian dipelihara oleh peternak selaku pengelola, setelah dipelihara dalam beberapa waktu, sapi tersebut kemudian dijual. Hasil penjualan sapi dikurangi dengan modal untuk membeli sapi. Kemudian sisa dari penjualan sapi kemudian dibagi berdasarkan kesepakatan diantara. Sebagaimana sistem yang digunakan di Desa Watu Kecamatan Barebbo, praktek semacam ini banyak digunakan. Sapi yang digemukkan diperuntukkan untuk sapi potong dan sapi untuk kebutuhan kurbann(Tahang, 2018). Hal ini sejalan dengan apa yang dijelaskan oleh Kusnadi bahwa salah satu bentuk sistem bagi hasil peternakan sapi didasarkan pada laba kotor. Sistem bagi hasil yang berbasiskan laba kotor adalah sistem bagi hasil yang didasarkan pada pendatan yang diperoleh setelah dikurangi dengan biaya biaya variabel yang dikeluarkan dalam proses produksi. Model ini digunakan dengan pertimbangan adalah penerima dan pemberi modal melalui terbentuk hubungan yang saling amanah (percaya).

Selanjutnya sistem kedua adalah bagi hasil berdasarkan pendapatan. Cara semacam ini dilakukan oleh masyarakat di Desa Kajaolaliddong dan Kelurahan Apala. Pemilik sapi membeli sapi untuk kemudian dipelihara oleh si peternak, setelah beberapa waktu, sapi tersebut dijual dengan harga yang berlaku di tempat tersebut. Hasil penjualan dikurangi dengan modal dan biaya yang dikeluarkan peternak. Sistem bagi hasil berdasarkan pendapatan (Revenue Sharing System, $R S S$ ), sistem bagi hasil yang berbasiskan pendapatan adalah sistem bagi hasil yang didasarkan pada pendapatan yang diperoleh sebelum dikurangi dengan biayabiaya yang dikeluarkan dalam proses produksi. Model bagi hasil ini digunakan 
Sitti Nikmah Marzuki:Prakterk Bagi Hasil Peternakan...

dengan beberapa pertimbangan yaitu, penerima modal yang akan merugikan pemberi modal, misalnya manipulasi laporan keuangan yang cenderung membesarkan biaya-biaya yang dikeluarkan untuk menghindari pembayaran bagi hasil dan antara penerima dengan pemberi modal belum terbentuk hubungan yang saling percaya.

Di sisi lain sistem bagi berdasarkan laba operasi bersih (Operating Profit Sharing System, OPSS). Sistem bagi hasil yang berbasiskan laba operasi kotor adalah sistem bagi hasil yang didasarkan pendapatan yang diperoleh setelah dikurangi dengan biayabiaya variabel dan biaya-biaya serta biaya lain. Model ini digunakan dengan pertimbangannya adalah antara penerima dam pemberi modal terbentuk hubungan yang saling amanah (percaya).

a. Sistem bagi hasil berdasarkan laba bersih (Net Profit Sharing System, NPSS)

Sistem bagi hasil yang berbasiskan laba bersih adalah sistem bagi hasil yang didasarkan pada pendapatan yang diperoleh setelah dikurangi dengan biaya biaya variabel dan biaya-biaya tetap serta biaya-biaya lainnya dan telah dikurangi pajak yang harus di bayarkan. Model ini digunakan dengan pertimbanga antara penerima dan pemberi modal karena benar-benar telah saling percaya, transparan dan profesional.

\section{KESIMPULAN}

Berdasarkan pembahasan di atas, maka penulis mengemukakan beberapa kesimpulan dalam penelitian ini sebagai berikut:

1. Sistem peternakan sapi di Kecamatan Barebbo pada umumnya menggunakan tiga sistem yaitu teknik pemeliharaan ekstensif, teknik pemeliharaan intensif dan teknik pemeliharaan semiintensif. Teknik pemeliharaan yang dominan dilakukan adalah semiintensif, hal ini ditunjukkan dengan hampir seluruh masyarakat di Kecamatan Barebbo memelihara dengan mengandangkan sapi saat musim tanam petani dan melepaskan sapi di alam bebas jika masa panen petani telah usai.

2. Pendapatan masyarakat Peternak Sapi Kecamatan Barebbo Kabupaten Bone masih pada kisaran rata-rata pendapatan peternak sapi umumnya masih berkisar Rp. 2.000.000 - Rp. 5.000.000 setiap satu ekor sapi tergantung dari kondisi sapi dan teknik bagi hasil yang disepakati. Jika peternak melakukan kerjasama ternak sapi 2 sapi maka peternak akan memiliki keuntungan yang lebih besar.

3. Praktek pengembangan peternakan sapi berbasis bagi hasil pada dasarnya berdasarkan sistem bagi hasil anakan sapi dan bagi hasil penggemukan sapi. Sistem anakan sapi dibagi sesuai kondisi indukan sapi, jika sapi telah melahirkan sebelumnya maka anak pertama menjadi milik si pemilik sapi dan jika induk sapi belum pernah melahirkan, maka anak pertama yang lahir menjadi hak peternak sapi. Sistem bagi hasil didasarkan pada yang dilakukan Sistem bagi hasil yang diterapkan berdasarkan pendapatan, bagi hasil berdasarkan laba kotor dan bagi hasil berdasarkan laba bersih. Sistem bagi hasil yang paling dominan digunakan oleh masyarakat peternak sapi di Kecamatan Barebbo adalah bagi hasil berdasarkan laba kotor. Sistem ini dipandang lebih adil dan memberikan mashlahah kepada kedua belah pihak. Sistem ini dapat meningkatkan ekonomi masyarakat peternak di Kecamatan Barebbo Kabupaten Bone.

\section{SARAN}


Islamiconomic: Jurnal Ekonomi Islam

Vol.10 No.1 Januari - Juni 2019

1. Penelitian ini menjadi dasar perubahan kebijakan pemerintah desa dalam memberlakukan bagi hasil peternakan sapi di Kabupaten Bone

2. Penelitian ini menjadi bahan pertimbangan dinas peternakan dalam memberikan bantuan kepada masyarakat khususnya program pemerintah dalam Amembantu peternak sapi dalam meningkatkan kesejahteraannya. 


\section{DAFTAR REFERENSI}

Abdurrahman Al Bassam, Abdullah, 2006. Syarah Bulughul Maram, penerjemah Thahirin Suparta, M.Faisal, Adis Al dizar: Editor, Mukhlis B Mukti, Jakarta: Pustaka Azzam.

Arikunto, Suharsimi, 2005. Metodologi Penelitian, PT. Asdi Mahasatya, Jakarta.

Asdar, Pengelola Sapi, 2017. Wawancara, Kelurahan Apala Kecamatan Barebbo Kabupaten Bone Tanggal 30 April 2017.

Al-Asqalani, Ibnu Hasan, 1988. Bulughul Maram, penerjemah thahirin Suparta, Bandung: CV. Diponegoro.

Boediono, 2002. Pengantar Ekonomi, Jakarta: Erlangga

Danil, Mahyu, 2014. Pengaruh Pendapatan Terhadap Tingkat Konsumsi pada Pegawai Negeri Sipil di Kantor Bupati Kabupaten Bireuen, Journal Ekonomika Universitas Almuslim Bireuen Aceh, Vol. IV No. 7

Depertemen Agama Islam, 1995. Al-Qur'an dan Terjemahannya, Surabaya :Al-Ikhlas,

Fatimah, Siti, 2011. Pelaksanaan Sistem Bagi Hasil Peternak Sapi di Desa Sejangat ditinjau Menurut Konsep Mudharabah, Skripsi, Universitas Islam Negeri Sultas Syarif Kasim Riau.

Ghazaly, Abdaul Rahman dkk., 2010..Fiqh Muamalat, Edisi 1, Cet. 1, Jakarta: Kencana. Hadi,Sutrisno, 1999. Metodologi Research, Yogyakarta: Lkis.

Ilmi, Makhalul, 2002. Teori dan Praktik Lembaga Keuangan Syariah, Yogyakarta: UII Press Yogyakarta.

Mamma Dg. Situru, 2017. Pengelola Sapi, Wawancara, Desa Pajekko Kecamatan Barebbo Kabupaten Bone Tanggal 28 April 2017.

Marbun, 2003. Kamus Manajemen, (Jakarta: Pustaka Sinar Harapan

Muhammad, 2002. Manajemen Bank Syariah, Yogyakarta: UPP AMP YKPN, 2002.

Nata, Abudin, 2003. Metodologi Studi Islam, Jakarta: PT Raja Grafindo Persada,

Nurfadillah, Hasan, Nurdin Hasan, Peternak Sapi, Masyarakat Kecamatan Barebbo (Peternak Sapi), Congko, 19 Agustus 2018.

Pusat Pengkajian dan Pengembagan Ekonomi Islam, 2008. Ekonomi Islam. Ed. 1, Cet. 1; Jakarta: PT. RajaGrafindo Persada.

Puspitasari, Ita, 2014. Motivasi Peternak Melakukan Sistem Bagi Hasil (Teseng) UsahaTernak Sapi Potong Di Desa Lempang Kecamatan Tanete Riaja Kabupaten Barru. Skripsi . .Makasar: Universitas Hasanuddin Makassar. 2014.

Qal'ahji, M. Rawwas, tth. Ensiklopedi Fiqh Umar bin Khatab ra, Jakarta : PT. Raja Grafindo Persada.

Reksoprayitno, 2004. Sistem Ekonomi dan Demokrasi Ekonomi, Jakarta: Bina Grafika,

Rohani, Puspitasari. I, dan Abdullah A, 2014. Karakteristik Peternak Sapi Potong Dengan Sistem Bagi Hasil Di Desa Lempang, Kecamatan Tanete Riaja, Kabupaten Barru. Makassar: Universitas Hasanuddin.

Sabiq, Sayyid, tth. Fikih Sunnah, Cet. 8, Bandung: PT. Al-ma'arif.

Soekartawi, 2004. Faktor-faktor Produksi, Jakarta: Salemba Empat

Syafi'i, Rachmat, 2004. Fiqih Muamalah Untuk IAIN,STAIN,PTAIS, dan Umum, Bandung: Pustaka Setia.

Toweulu, Sudarman, 2001. Ekonomi Indonesia, Jakarta: Raja Grafindo. 
Islamiconomic: Jurnal Ekonomi Islam Vol.10 No.1 Januari - Juni 2019

Yusanto, Ismail dan M. Arif Yunus, 2009. Pengantar Ekonomi Islam, Cet. I, Bogor: AlAzhar Press.

al-Zuhaily, Wahbah. al-Fiqh al- Islam wal adillatuh,( Dar al- Fikri,tt), juz I.

\section{Catatan Akhir:}

